\title{
ANALISIS EFISIENSI PEMASARAN TELUR AYAM RAS DI CV.CIPTA AKSARA KELURAHAN KASTELA KECAMATAN KOTA TERNATE SELATAN
}

\author{
$\mathrm{H}$ a $\mathbf{m ~ k}$ a \\ Staf Pengajar FAPERTA UMMU-Ternate,e-mail : hamka_agb@yahoo.co.id
}

\begin{abstract}
ABSTRAK
Penelitian ini bertujuan mengetahui saluran pemasaran pada CV.Cipta Aksara dan tingkat efisiensi pemasarannya. Metode penelitian yang digunakan adalah metode kualitatif dengan pendekatan margin pemasaran, share harga dan rasio keuntungan. Hasil penelitian diperoleh bahwa model saluran pemasaran yang terbentuk dari proses pemasaran telur ayam ras di CV.Cipta Aksara terdiri dari 4 saluran pemasaran dimana saluran terpendek adalah produsen $\rightarrow$ Konsumen dengan tingkat efisiensi pemasaran $86 \%$ dengan tingkat efisiensi lebih dari $50 \%$ atau efisien, margin pemasaran Rp.200,- dengan rasio keuntungan Rp.1,5,sedangkan saluran terpanjang adalah Produsen $\rightarrow$ Pedagang Besar $\rightarrow$ Pedangan Menengah $\rightarrow$ Pedangan Kecil $\rightarrow$ konsumen. Dengan tingkat efisiensi yang terbentuk dari setiap saluran menunjukkan nilai lebih dari $50 \%$ yang berarti saluran pemasaran yang terbentuk efisien, tingkat margin pemasaran terbesar terbentuk pada saluran pemasaran ke 4 sebesar Rp.925 dengan tingkat rasio keuntungan Rp.9,- yang artinya setiap penambahan Rp.1,- oleh CV. Cipta Aksara maka perusahaan akan memperoleh keuntungan sebesar Rp. 9,-.
\end{abstract}

Kata Kunci: Saluran Pemasaran, Margin, Efisiensi, Keuntungan

\section{PENDAHULUAN}

\subsection{Latar Belakang}

Strategi pemenuhan protein hewani masyarakat hanya bisa dilakukan lewat pembangunan sektor peternakan. Menurut Rasyaf, 2001, Peternakan merupakan sub sektor yang menjadi alternatif pembangunan untuk memperkuat pelaksanaan kebijakan dan program revitalisasi pertanian dalam arti luas. Pengembangan usaha peternakan memiliki peran penting dalam peningkatan kesejahteraan dan taraf hidup masyarakat khususnya peternak, penyedia lapangan kerja bagi masyarakat, penopang sistem ekonomi perdesaan, serta mendukung pemenuhan kebutuhan akan protein hewani bagi masyarakat Indonesia.

Telur merupakan komoditi yang diminati oleh masyarakat, hampir semua masyarakat Indonesia menyukai dan menikmati telur sehingga permintaan akan telur menjadi meningkat. Secara langsung hal ini memberikan dampak langsung bagi perkembangan peternakan ayam ras petelur. Rasyaf, M. 2011, menyatakan bahwa efisiensi usaha peternakan unggas adalah hal yang sangat penting agar kualitas produk unggas bisa bersaing di pasar bebas, dan upaya yang harus dilakukan antara lain adalah substitusi bahan pakan, peningkatan mutu produk, peningkatan produktivitas ternak, pembinaan sumber daya manusia dan membentuk koperasi mandiri.

Populasi ayam ras petelur hingga saat ini telah menyebar keseluruh wilayah di Indonesia. Seiring meningkatnya permintaan dan kebutuhan akan telur, maka diperlukan peningkatan produksi dan pengembangan usaha oleh perusahaan-perusahaan peternakan khususnya ayam petelur. Keberhasilan suatu usaha peternakan ayam petelur dipengaruhi oleh 3 faktor utama yaitu, pakan, bibit, dan manajemen (Wahju, 1997). 
Peermasalah yang dihadapi oleh peternak ayam ras petelur adalah banyaknya jalur distribusi dimana sarana produksi tidak bisa seimbang dengan harga produksi. bahwa kemudahan dalam menjual hasil produksi merupakan faktor yang mendukung bagi keberhasilan ternak ayam ras petelur. Namun hal itu tidak akan berarti jika peternak tidak mampu mengelola dengan baik saluran pemasaran yang ada, dengan mempertimbangkan tingkat efisiensi dari semua saluran yang ada, dimana akan sangat berpengaruh langsung terhadap pendapatan peternakan ayam ras petelur.

\subsection{Perumusan Masalah}

Permasalahan yang menjadi bahan kajian dalam penelitian ini adalah :

1. Model saluran pemasaran telur pada $C V$ Cipta Aksara di Kelurahan Kastela di kota ternate.

2. Bagaimana tingkat efisiensi pemasaran telur ayam ras oleh CV Cipta Aksara di Kelurahan Kastela.

\subsection{Tujuan Penelitian}

Tujuan penelitian yang ingin dicapai adalah :

1. Mengetahui Model saluran pemasaran telur ayam ras CV Cipta Aksara di Kelurahan Kastela di kota Ternate

2. Tingkat Efisiensi pemasaran telur ayam ras pada CV Cipta Aksara di Kelurahan Kastela.

\section{METODE PENELITIAN}

\subsection{Waktu dan Lokasi Penelitian}

Penelitian ini dilaksanakan selama tiga bulan yang akan berlangsung sejak bulan oktober sampai desember 2012. Lokasi yang akan dijadikan tempat penelitian adalah $\mathrm{CV}$. Cipta Aksara yang bertempat usaha di Kelurahan Kastela Kecamatan Pulau Ternate.

3.2. Teknik Pengambilan Sampel

Metode yang digunakan dalam pengambilan sampel peternak adalah Judgment Sampling, dimana sumber informasi yang diterima adalah dari pengusaha telur ayan ras pada CV. Cipta Aksara. judment sampling umumnya memilih sesuatu atau seseorang menjadi sampel karena mereka mempunyai “information rich". (Cooper dan Emory, 1996).
Sementara itu untuk mendapatka informasi terkait saluran pemasaran digunakan teknik snawball sampling. Dengan teknik ini peneliti akan mendapatkan informasi terkait pedangan-pedangan yang terlibat dalam pemasaran telur ayam ras. Adapun jumlah sampel 38 oarng yang terdiri dari 1 orang produsen atau peternak ayam ras petelur pada CV. Cipta Aksara, 2 orang pedangan Besar, 5 Orang pedangang eceran, 10 orang pedangan kecil, dan 20 orang konsumen.

3.3. Teknik Analisi Data

Hanafiah dan Saefuddin, (1986) rumus magrin pemasaran adalah sebagai berikut :

1. Analisis Margin Pemasaran

$$
\mathrm{Mp}=\operatorname{Pr}-\mathbf{P f}
$$

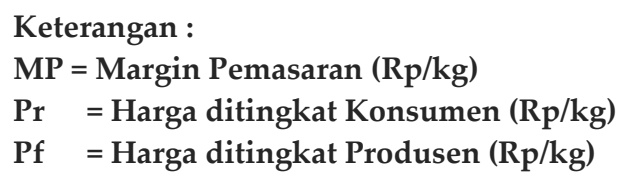

2. Analisis Share Harga yang diterima peternak

Share harga yang diterima peternak merupakan proporsi dari harga yang diterima peternak terhadap biaya yang dibayar konsumen akhir :

$\mathrm{SPF}=(\mathrm{Pf} / \mathrm{Pr}) \times 100 \%$

Keterangan :

SPF = Share harga di tingkat peternak (\%)

Pf = Harga ditingkat peternak $(\mathrm{Rp} / \mathrm{kg})$

$\operatorname{Pr}=$ Harga ditingkat konsumen $(\mathrm{Rp} / \mathrm{kg})$

3. Analisis Share biaya pemasaran dan share keuntungan lembaga pemasaran.

Share biaya dan share keuntungan pemasaran dapat dihitung dengan rumus :

$S k_{i}=\left(K_{i}\right) /(P r-P f) \times 100 \%$
$S b_{i}=\left(B_{i}\right) /(P r-P f) \times 100 \%$

$\mathrm{Sb}_{\mathrm{i}}=\left(\mathrm{B}_{\mathrm{i}}\right) /($

$\mathrm{Sk}_{\mathrm{i}}=$ share keuntungan lembanga pemasaran ke-i

$S b_{i}=$ Share biaya pemasaran ke-i

Adapun kriteria yang digunakan adalah sebagai berikut :

a. Apabila perbandingan share keuntungan dari tiap lembaga yang terlibat dalam pemasaran tidak merata, maka sistem pemasaran dikatakan tidak efisien.

b. Apabila perbandingan share keuntungan dari tiap lembaga yang terlibat dalam pemasaran merata, maka sistem pemasaran dikatakan efisien. 
III. GAMBARAN UMUM PERUSAHAAN

3.1. Sejarah Berdirinya dan Perkembangan Perusahaan

Peternakan CV.Cipta Aksara didirikan pada bulan februari 2010 dengan jumlah DOC atau bibit ayam petelur sebanyak 600 ekor. Namun pada bulan ke tiga, penyakit menyerang unggas ini hingga menyebabkan kematian hingga $80 \%$. Pada bulan maret perusahaan menambah jumlah bibit ayam petelur yang berjumlah 1000 ekor, dan terus bertambah hingga saat ini berjumlah \pm 5000 ekor.

Drs. Umar Bopeng sebagai pemilik sekaligus pengelolah perusahaan ini memilih lokasi peternakan di daerah Kastela kecamatan Ternate Selatan yang berjarak kurang lebih $12,5 \mathrm{~km}$ dari pusat Kota Ternate. Perusahaan peternakan ini berdiri diatas tanah seluas 1,2 Ha. Usaha yang didirikan Drs. Umar Bopeng ini juga merupakan satu-satunya usaha peternakan ayam ras petelur di Kota Ternate.
Peternakan CV.Cipta Aksara ini merupakan perusahaan perseorangan. Latar belakang pendirian perusahaan ini pada mulanya pemilik memiliki modal dan tertarik dengan jenis usaha peternakan ini.

\subsection{Struktur Organisasi}

Struktur organisasi perusahaan adalah suatu gambaran yang sistematis mengenai tugas dan tanggung jawab serta hubunganhubungan dalam suatu organisasi perusahaan agar kegiatan organisasi tersebut lebih terarah dalam pencapaian tujuan. Dengan adanya tugas, wewenang dan tanggung jawab tersebut, pimpinan akan mudah mengkoordinir dan mengarahkan karyawan didalam usahanya mencapai tujuan yang telah ditetapkan bersama. Berikut struktur organisasi peternakan ayam ras petelur CV. Cipta Aksara:

Struktur Organisasi Peternakan Ayam ras petelur CV. Cipta Aksara: (Gambar 1).

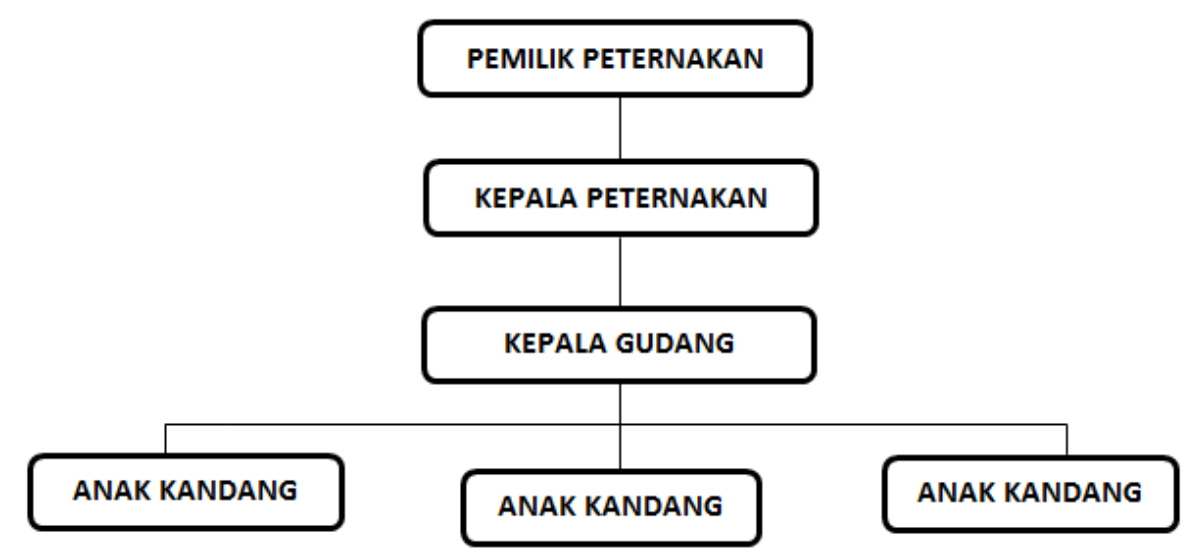

Gambar 1. Struktur Organisasi.

\subsection{Modal Investasi}

Biaya investasi untuk usaha ternak ayam ras petelur CV.Cipta Aksara terdiri dari pembelian lahan, bangunan kandang, peralatan kandang, gudang, peralatan gudang, instalasi listrik dan bangunan untuk tempat tinggal pekerja. Biaya pembelian lahan seluas 1,2 $\mathrm{Ha}$ sebesar Rp. 350.000.000. Sedangkan biaya investasi bangunan kandang sebanyak 3 buah, peralatan kandang, gudang, peralatan gudang, instalasi listrik, dan bangunan tempat tinggal pekerja adalah Rp.1.031.352.000. Perusahaan peternakan CV.Cipta Aksara ini merupakan perusahaan perseorangan dan modal investasinya didanai dengan dana sendiri.

\section{PEMBAHASAN}

\subsection{Fungsi Pemasaran Telur Ayam Ras}

Fungsi-fungsi pemasaran dilakukan oleh lembaga-lembaga pemasaran yang terlibat didalamnya. Tidak semua jenis fungsi pemasaran dilakukan oleh semua lembaga pemasaran. Ada kalanya suatu fungsi pemasaran tertentu dilakukan oleh satu lembaga atau beberapa lembaga, tetapi tidak dilakukan oleh lembaga lainnya. Selain itu ada fungsi pemasaran tertentu yang dilakukan oleh semua lembaga yang terlibat. Adapun fungsi pemasaran yang terjadi pada pemasaran telur ayam ras disajikan pada Tabel 1 . 
Tabel 1. Pelaksanaan Fungsi Lembaga Pemasaran

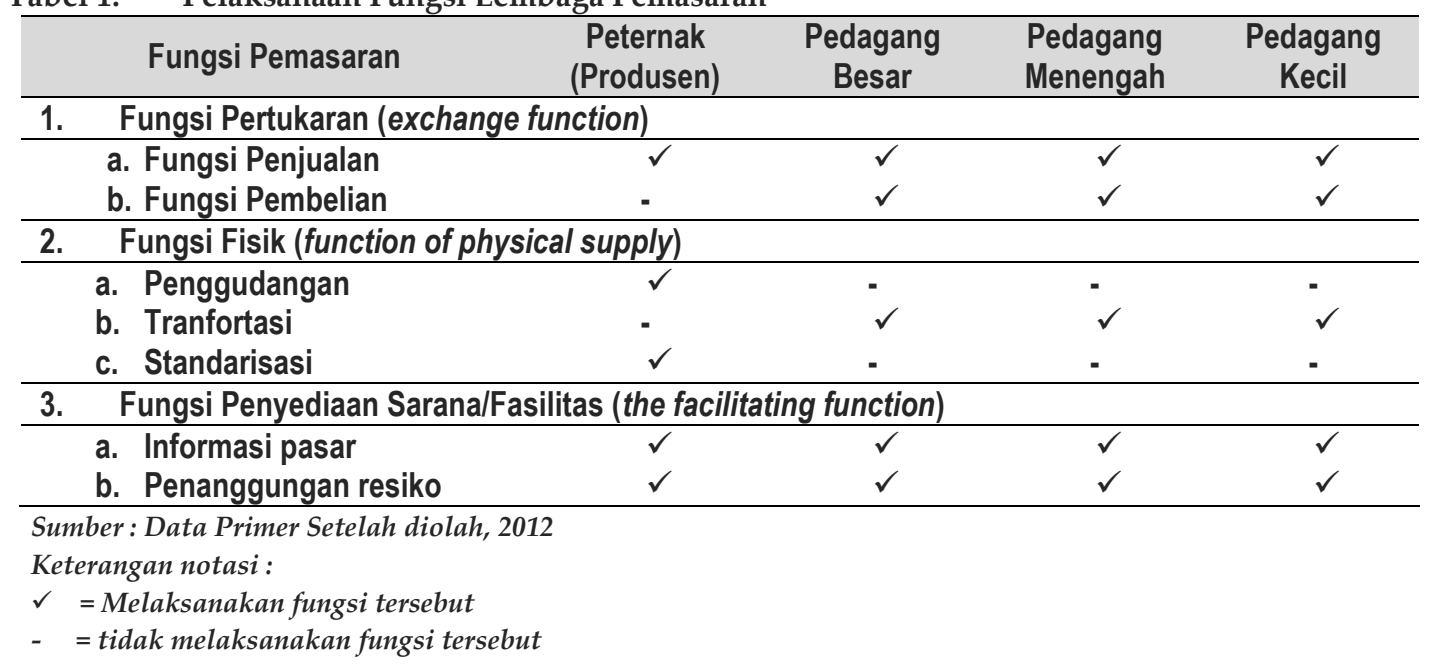

\subsection{Saluran Pemasaran}

Pola saluran pemasaran telur ayam ras yang terjadi dapat dilihat pada Gambar 2.

\subsubsection{Saluran Pemasaran I}

Saluran pertama adalah proses pemasaran dari produsen $\rightarrow$ langsung ke konsumen. Dengan harga jual yang harus dibayarkan oleh konsumen seharga Rp. 1.200,/butir. Di kota ternate sendiri, diseluruh pasar penjualan telur dikenakan harga perbutir dan bukan perkilogram telur.

\subsubsection{Saluran Pemasaran II}

Saluran Kedua adalah proses pemasaran telur ayam ras dari Produsen $\rightarrow$ Pedangan Besar $\rightarrow$ Konsumen. Pada saluran pemasaran kedua ini harga yang harus dibayarkan oleh masing-masing saluran adalah pedagang besar membayar perputir telur seharga Rp.1.200,- dan konsumen yang melakukan pembelian pada pedangan besar dengan biaya sebesar Rp 1.400,/butir.

\subsubsection{Saluran Pemasaran III}

Saluran ketiga adalah proses pemasaran telur ayam ras dari produsen $\rightarrow$ Pedangan Besar $\rightarrow$ Pedangang Menengah $\rightarrow$ Konsumen. Pada saluran ketiga produsen menjual ke pedagang besar dengan harga Rp.1.200,-/butir, kemudian pedangan besar menjual kepada pedangan menengah dengan harga Rp. 1.300,-/butir, kemudian pedangang menengah menjual kepada konsumen dengan harga Rp.1.700/butir.

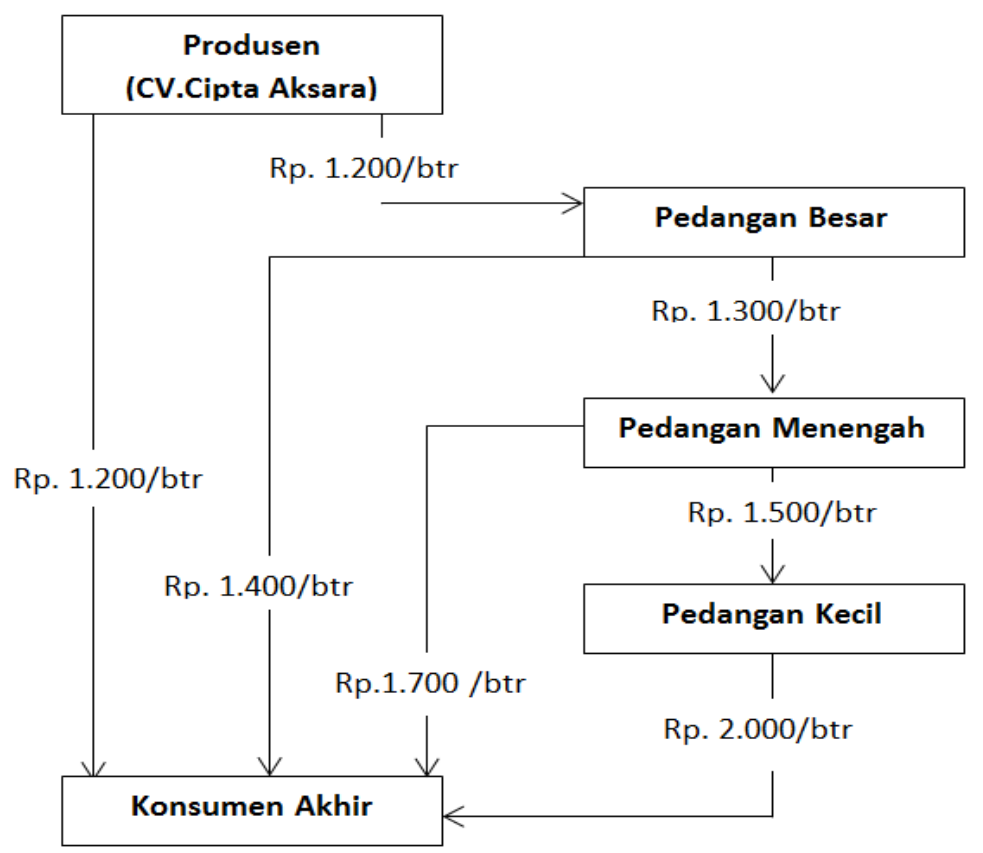

Gambar 2. Saluran Pemasaran Telur Ayam Ras 
Tabel 2. Margin Pemasaran Telur Ayam Ras pada Saluran Pemasaran II

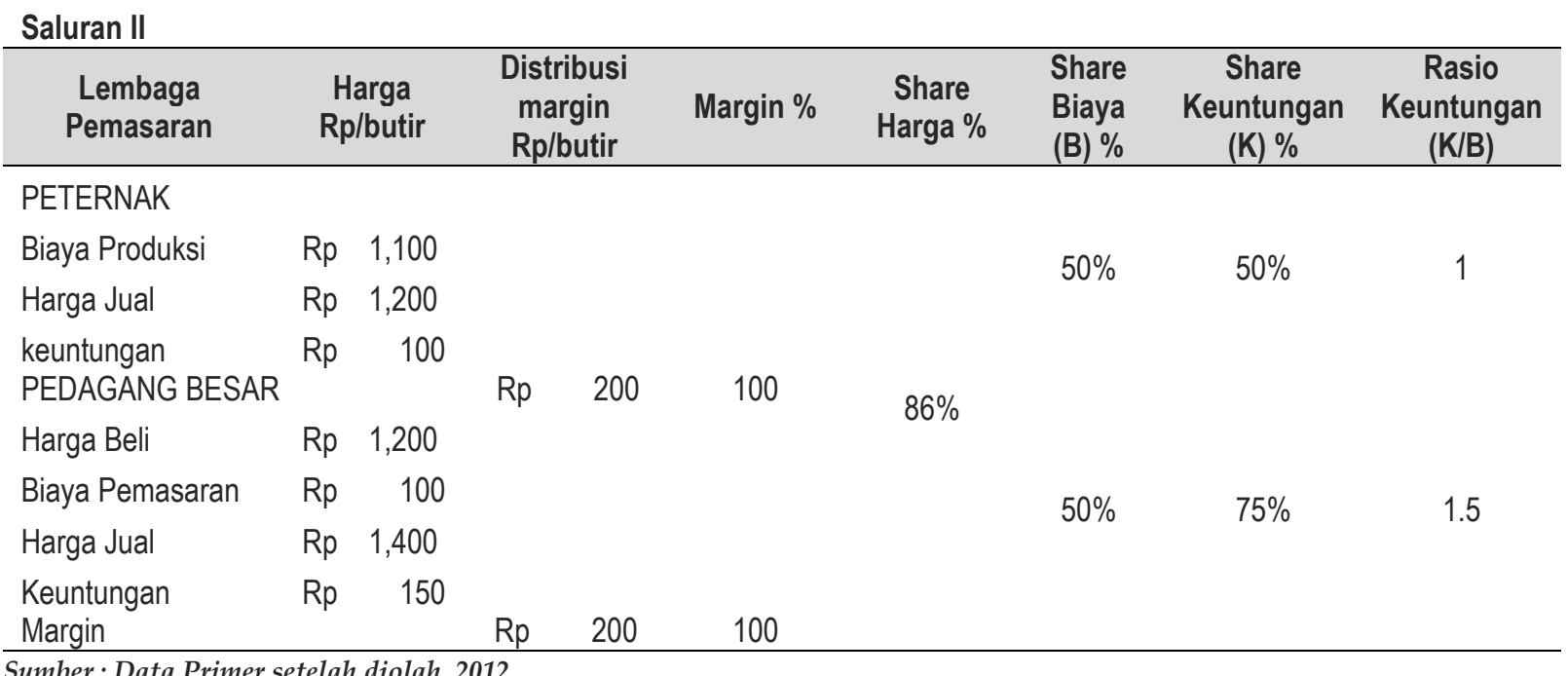

\subsubsection{Saluran Pemasaran IV}

Pada Tabel 2. di atas terlihat pola pemasaran yang terbentuk adalah pola pemasaran II dimana produsen $\rightarrow$ Pedangan Besar $\rightarrow$ Konsumen dengan margin pemasaran yang terbentuk sebesar Rp. 200,- sedangankan share harga sebesar $86 \%$ karena nilai share harga lebih besar dari $50 \%$ maka pemasaran dapat dikatakan efisien. Rasio keuntungan yang diperoleh sebesar Rp.1.5,- Artinya setiap pengeluaran biaya yang dilakukan oleh produsen sebesar Rp. 1,-, maka produsen akan memperoleh keuntungan sebesar Rp.1.5,-

Margin pemasaran telur ayam ras pada salauran pemasaran ke-3 dapat dilihat pada Tabel 3.

Tabel 3. Margin Pemasaran Telur Ayam Ras pada Saluran Pemasaran III

Saluran III

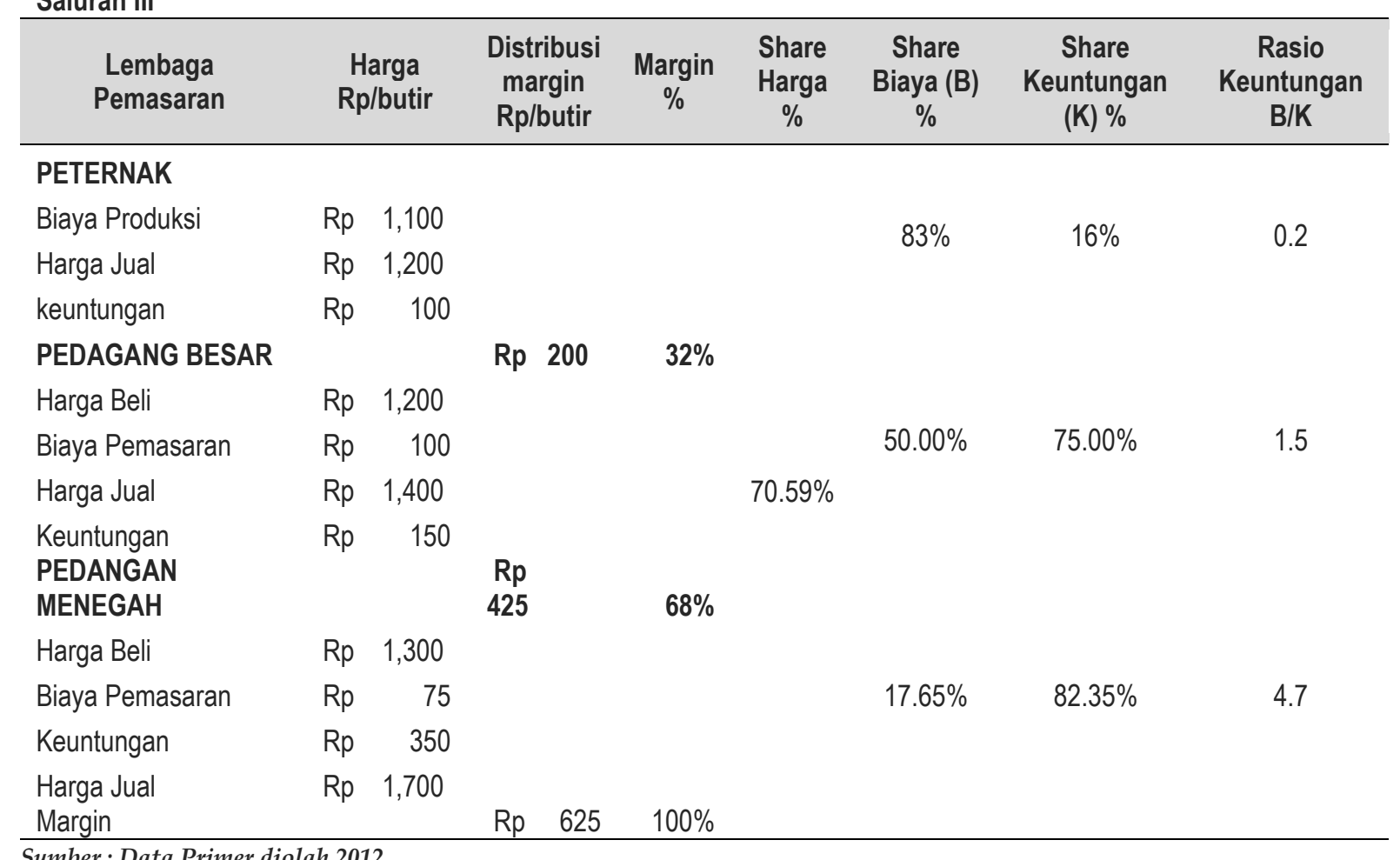

Sumber : Data Primer diolah,2012 
Pada Tabel 3 terlihat pola pemasaran yang terbentuk adalah pola pemasaran II dimana produsen $\rightarrow$ Pedangan Besar $\rightarrow$ Pedangan Menengah $\rightarrow$ Konsumen dengan margin pemasaran yang terbentuk sebesar Rp. 625 ,- sedangankan share harga sebesar $70.59 \%$ karena nilai share harga lebih besar dari $50 \%$ maka pemasaran dapat dikatakan efisien.
Rasio keuntungan yang diperoleh sebesar Rp.4.7,-. Artinya setiap pengeluaran biaya yang dilakukan oleh produsen sebesar Rp. 1,-, maka produsen akan memperoleh keuntungan sebesar Rp. 4,7,-

Margin pemasaran telur ayam ras pada salauran pemasaran ke-3 dapat dilihat pada Tabel 4.

Tabel 4. Margin Pemasaran Telur Ayam Ras pada Saluran Pemasaran IV

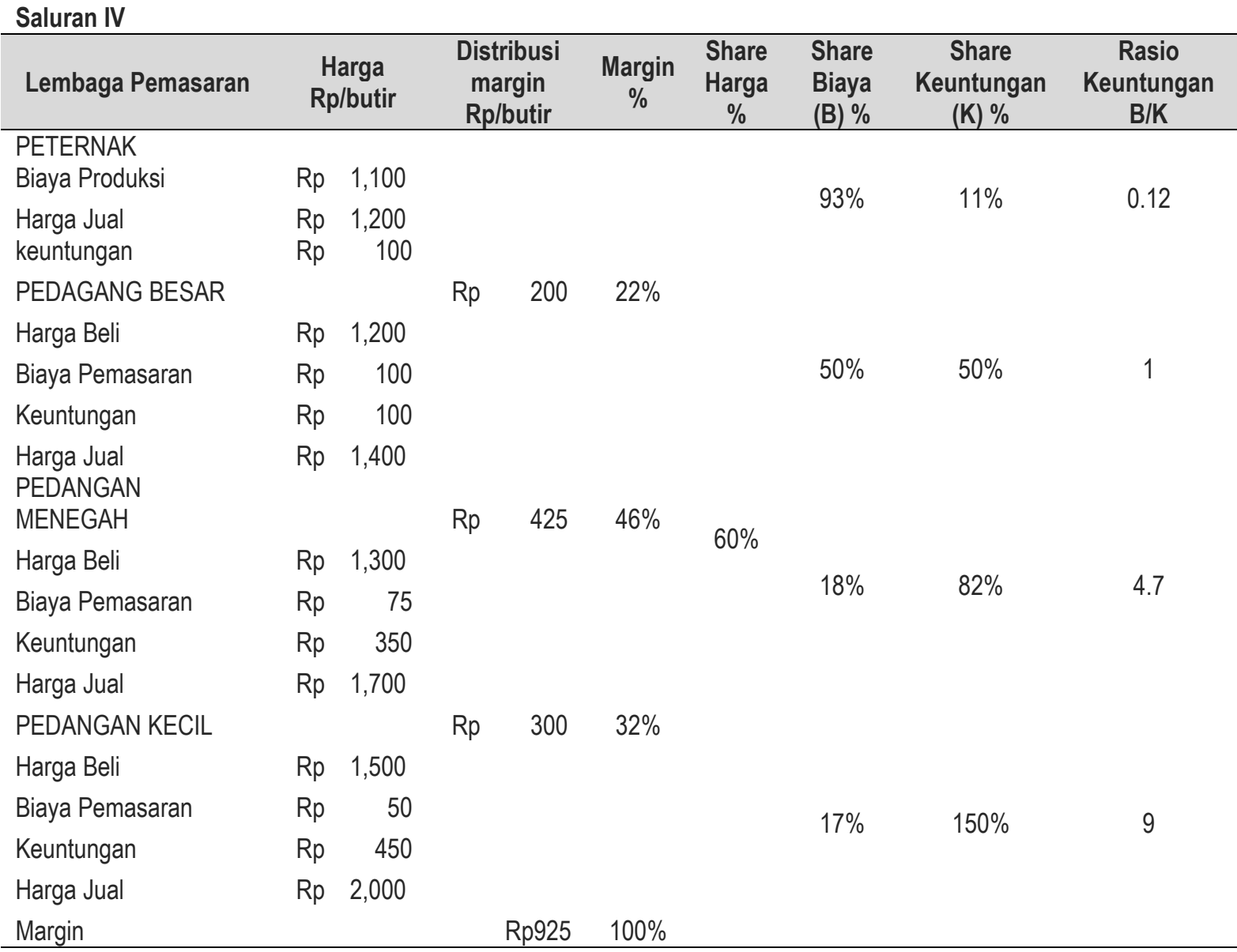

Sumber: Data Primer Setelah di Olah,2012

Pada Tabel 4 terlihat pola pemasaran yang terbentuk adalah pola pemasaran II dimana produsen $\rightarrow$ Pedangan Besar $\rightarrow$ Pedangan Menengah $\rightarrow$ Pedagang Kecil $\rightarrow$ Konsumen dengan margin pemasaran yang terbentuk sebesar Rp. 625,- sedangankan share harga sebesar $60 \%$ karena nilai share harga lebih besar dari $50 \%$ maka pemasaran dapat dikatakan efisien. Rasio keuntungan yang diperoleh sebesar Rp 9. Artinya setiap pengeluaran biaya yang dilakukan oleh produsen sebesar Rp. 1,-, maka produsen akan memperoleh keuntungan sebesar Rp. 9,-

\section{PENUTUP}

Saluran pemasaran yang terjadi dalam penjualan telur ayan ras pada CV. Cipta Aksara terdiri dari 4 jalur pemasaran, dimana tiap-tiap jalur menunjukkan tingkat efisiensi pemasaran yang baik hal ini ditunjukkan dengan nilai share harga lebih dari $50 \%$, dimana setiap penambahan Rp.1,- oleh produsen telur ayam ras akan memberikan keuntungan kepada produsen memberikan keuntungan pada saluran II sebesar Rp. 1,5,-, saluran III sebesar Rp. 4,7,- dan saluran III sebesar Rp. 9,- , dengan demikian proses pemasaran yang terjadi pada CV.cipta Aksara dapat dikatanan efisien. 


\section{DAFTAR PUSTAKA}

Coper, David R. And Emory, C. William (1996), Metode Penelitian Bisnis Jilid 1, edisi ke 5, Erlangga. Jakarta.

Direktorat Jenderal Peternakan dan Kesehatan Hewan, 2010. Ketersediaan Konsumsi Telur dan Daging Menurut Provinsi.

Merdeka, B. 2010. Sukses Beternak Ayam Petelur. Atma Media Press. Jakarta.

Prawirokusumo, S. 1990. Ilmu Usaha Tani. BPFE. Yogyakarta.

Rasyaf, M. 2011. Panduan Beternak Ayam Petelur. Penebar Swadaya, Jakarta.

Ridwan, Sunarto. 2009. Pengantar Statistika Modern Untuk Ilmu Social,

Wahju, J. 1997. Ilmu Nutrisi Unggas. Penerbit Gadjah Mada University Press, Yogyakarta. 